\title{
THE ALBUQUERQUE GEOLOGICAL MEETING.
}

\author{
A RES U ME OF THE PROCEEDINGS.
}

\section{B Y EDMUND OTIS HOVEY}

ON December 30 and 31, 1907, the Geological Society of America met at the University of New Mexico, Albuquerque, for its twentieth annual meeting. About thirty members of the society were present, all but one of whom had traveled from half a day to four days to attend the meeting. The exception was Prof W. G. Tight, president of the university, who wa responsible for getting the society to meet in Albuquerque, and by reason of whose admirable arrangements the meeting was one of the most satisfactory the society has ever held. The presiding officers were: President, Charles R. Van Hise, of the University of Wisconsin, Madison, Wis.; first vice-president, Mr. J. S. Diller, of the United States Geological Survey, Washington, D. C.; second vice-president, Prof. A. P. Coleman, of Toronto University, Toronto, Canada The report of the secretary, Dr. E. O. Hovey, of the American Museum of Natural History, New York city, showed 294 names on the list of members. The fourteen members elected at the New York meeting in December, 1906, qualified during the year, but two were lost by death and one by resignation, leaving a net gain of eleven over the latest printed list

The two members who died were Prof. James Safford and Angelo Heilprin. Prof. Safford was a man eightyfive years of age, a pioneer of geology in America, who spent most of his active scientific life in Tennessee. Prof. Heilprin was only fifty-four years old, and would probably have had many additional years to live and work, had not the hardships of exploration in the tropics brought on fatal disease. An intrepid explorer in many zones and climates,. he was a fascinating lecturer to students and the general public and his loss will be deeply felt by many.

Fifty-two papers were listed in the programme, bu absence of the authors cut the number actually presented in whole or in part down to twenty. Prof F. R. Van Horn, of Cleveland, Ohio, read a paper "On the Occurrence of Proustite and Argentite at the California Mine near Montezuma. Colorado," in which he stated that these enormously rich silver ores occurred in seams sometimes two inches thick along the middle of a banded vein of argentiferous galena associated with sphalerite. The next paper was by Dr. A. C. Lane, State Geologist of Michigan, "On the 'Field Assay' of Mine Waters." The author showed the need there is of supplementing by tests and analyses of mine waters the theory of ore deposition by circulat ing underground waters, and exhibited a pocket total reflectometer, which he had devised for the purpose of making rough tests in mines.

Prof. A. P. Coleman, of Toronto, Canada, discussed "Glacial Periods and Their Bearing on Geological Theories," saying that four well-defined glacial periods were known in geological history, occurring in the Pleistocene, and Permo-Carboniferous, the Lower Cambrian, and the Lower Huronian, final proofs of the last-named glacial period having been obtained only recently. The author stated that the wide distribu tion of glacial deposits in at least three of these periods proves that refrigeration was general and included both hemispheres, and that there was evidence of important interglacial periods in three of the ice ages. He concluded the paper by pointing out the importance of these facts as bearing on the origin importance of these facts as bearing on the origin
and early history of the earth and on the factors which cause variations of climate. The active discussion that followed the reading of this paper showed that the evidence for the existence of a glacial period in Lower Huronian time was not considered conclusive by all the geologists present, since surfaces which were the geologists present, since surfaces which were
glacially striated during that period had not yet been found.

"The Chief Features of the Stratigraphy and Structure of Mount Diablo, California," was the title of a paper by Prof. George D. Louderback, of Berkeley, Cal., in which the following considerations were brought forward: Mount Diablo is a distinctive feature of the central Coast ranges because it rises from low valleys on practically all sides, and is not mérely a more prominent peak of a continuous range. It shows a remarkably complete stratigraphic series of the characteristic Coast Range formations. Structurally, it is an overturned and overthrust anticline of very late origin. There is also evidence of an of very late origin. There is also evidence of an
earlier structural form. The geology of Mount Diablo may be taken as showing a stratigraphic succession and an orogenic history characteristic of the coast ranges from the Klamath Mountains to the Tehachapi. Prof. H. P. Cushing, of Cleveland, Ohio, then read a paper on "The Lower Portion of the Paleozoic Section in Northwestern New York," which may be abstracted as follows: In Jefferson County, N. Y., in the district between Watertown and Alexandria Bay, the Potsdam sandstone and the Lowville, Black River, and Trenton limestones are present in quite normal expression. Between the Potsdam and the Lowville are two additional formations. The lower of these passes nto the Potsdam by gradation, and is lithologically like similar "passage beds" elsewhere in northern New York. It consists of alternating sands and sandy dolomites, varies in thickness from 15 to 75 feet, and has an erosion unconformity at its summit. It is overlain by an impure limestone formation, which overlaps on the district from west to east, reaches a thickness of 125 feet, and holds a fauna not hitherto noted in New York, which is tentatively correlated by Dr. E. O. Ulrich with that of the upper Stones River formation of Southern Pennsylvania. It has close relationship to the Lowville formation above. The Chazy formation is absent, as is also the entire Beekmantown. The physical break between the two formations is the most. prominent one as yet noted in the New York Lower Silurian. The section is compared with those east and south of the Adirondacks, and the additional light. which it throws on the physical oscillations of the region is considered.

The afternoon session of the first day's meeting began with the reading of the annual address by the retiring president, President Charles R. Van Hise of the University of Wisconsin, which discussed "Th Problem of the Pre-Cambrian." President Van Hise has devoted many years to the study of the problems presented by the Pre-Cambrian rocks, which are the most puzzling of all those within the range of geology. The nature of the paper precludes any effort at condensing it for these columns.

The next paper read was unon "The Relation of the Equus Beds of Kansas to Reversed Mississippi Drainage," by President W. G. Tight of the University of New Mexico. The Equus beds are deposits of early Pleistocene age, and the author considers that the facts observed in the field show that during their deposition the northern portion of the Mississippi valley drained northward.

In a paper upon "The Grenville-Hastings Unconformity," Messrs. Willet G. Miller and Cyril W. Knight of the Bureau of Mines, Toronto, gave the results of recent studies bearing upon some of the question discussed in the presidential address. The author said in part: The crystalline limestone and associated Pre-Cambrian sedimentary rocks of southeaster Ontario, and the adjacent parts of the Province of Quebec, to which Logan and his colleagues long ag gave the names of Grenville and Hastings series, have never been satisfactorily classified as regards their age. Recent work by the authors has shown that much at least of that which has been called the Hastings series consisting of limestones, conglomerates, and othe fragmental rocks, is much younger than, and forms well-defined unconformable series with, the typical crystalline limestones and associated fragmental rocks of what has been called the Grenville series proper. The view that the Grenville and Hastings constitute one series, the former being a more highly altere phase of the latter, is no longer tenable. The Keewatin series of the Lake Superior region is represented in southeastern. Ontario by ancient rocks. of like character. The Grenville limestones have bee deposited on the surface of the Keewatin. The authors class the Grenville limestone, as regards age, with the Keewatin iron formation of Lake Superior, which it has not been found possible in that region to separate from the greenstones. The Pre-Cambrian conglomerate and associated sedimentary rocks overlying, unconformably, the Grenville limestone, are classed as Huronian. The conglomerate contains not only ordnary fragments of the Grenville limestone, but "eozoon"-like bowlders as well, thus showing that the limestone is much older than the conglomerate. Moreover, the "pebbles of cherty and ferruginous rocks resembling those found in the iron ranges of the Lake Superior" in the conglomerate of eastern Ontario ar found to have been derived from layers or bands of this material in the Grenville limestone.

Dr. Alfred C. Lane, State Geologist of Michigan, followed with the announcement oi the determination of a new Silurian fauna in Michigan which had been made by Prof. W. H. Sherzer of Ypsilanti, Mich., an Prof. A. W. Grabau of New York city. The fauna oc curs in a limestone which usually consists of a mor or less condensed coral and stromatopora reef, to which the name of the Anderdon limestone has been given. The fauna is of a transition nature between Silurian and Devonian types. Dr. Lane then proceeded to a discussion of the "Nome ern New York," based upon investigations made largely for the Michigan Survey.

The concluding paper of the afternoon was on "The Structure and Stratigraphy of the Ouachita Ordovician Area, Arkansas," by Prof. A. H. Purdue of Fayetteville, Ark.

The second day's morning session opened with the consideration of the report of the committee favoring the establishment in territory belonging to the United States, Canada, and Mexico of a series of stations for the study of volcanie and seismic phenomena. This report was adopted, and then an overture was received looking toward the formation of a general committee on nomenclature, which should represent the several geological survey organizations of the United States, Canada, and Mexico, and also geologists not in connection with any official survey. At the end of the afternoon session this question was taken up again, thoroughly discussed, and the formation of $\cdot$ such a committee recommended.

The first scientific paper of the day was by Prof. John E. Wolff of Harvard University, in which he presented the results obtained by Dr. George $\mathrm{R}$. Mansfield of Harvard and himself in a study of the Crazy Mountains, Montana, made last summer. The Crazy Mountains are a most interesting district on account of their geology, petrography, and physiography, in cluding scenery. During the Glacial Period they were the seat of local glaciation. All the higher valleys contained small glaciers, as is indicated by the numerous cirques. Some of the glaciers on the south.and east slopes attained considerable size, notably those of Big Timber and Sweetgrass-American Fork canyons, which must have had lengths of approximately 15 to 18 miles, as shown by the extent of morainic deposits. Glaciation is not yet extinct. A tiny glacier was seen at the head of Big Timber and another in Sweetgrass canyon, and a third is reported by Assistant Forester Wilson at the head of Rock Creek. Glacial topography predominates throughout the southern section of the mountains and occurs locally in the southern section. Striæ and truncated valley-spurs along the sides of the canyons show that the ice must have been 500 to 800 feet thick. The glaciation succeeded a long erosion period, in which the region had reached an early stage of peneplanation. It continued long enough to form broad, deep troughs in the weaker rocks, and to produce much of the sharp arête topography so characteristic of the southern section of the mountains. Later stream erosion has incised the gl cial deposits, and in some cases the old troughs.

A paper on "The Sandia Mountains" was then read by President W. G. Tight, preparatory to an excursion planned for the day after the meetings.

In a paper on "The Topaz-Bearing Rhyolite of the Thomas Mountains, Utah," Prof. Horace B. Patton of the Colorado School of Mines at Golden, Colo., brought forward some interesting points with reference to the familiar topazes from Utah. Extensive rhyolite flows occur in the Thomas Mountains of Juab County, Utah, associated with somewhat more basic eruptives. The rhyolite has been profoundly affected by mineralizing vapors that have removed all trace of dark-colored constituents and have caused the development of a surprising number of topaz crystals, with occasional garnet and specular hematite. The topaz crystals occur (1) in lithophysal cavities associated with quartz, and are then mostly. clear crystals having a handsome brownish yellow wine-color that quickly dis-
appears on exposure to direct sunlight; (2) imbedded appears on exposure to direct sunlight; (2) imbedded
in the solid rhyolite and having frayed-out ends but in the solid rhyolite and having frayed-out ends but brownish in color before exposure to light, but are rendered opaque by numerous inclosures of quartz crystals. Similar crystals, but perfectly developed and with double terminations, were found imbedded in fragments of a very fine-grained rhyolite tuff, the fragments being themselves inclosed in rhyolite.

Mr. J. "S. Diller of the U. S. Geological Survey
hen read a paper on "The Strata Containing the Jurassic Flora of Oregon," in which he said in part: The Jurassic flora of Oregon has been described and designated by Profs. Lester F. Ward and William M. Fontaine in the U. S. Geological Survey, Twentieth Annual Report, pt. 2, p. 217, and Monograph 48. The localities of its occurrence have been greatly extended mong the Klamath Mountains of California, and sevin the same strata. On the one hand it is clearly 
associated with a characteristic Knoxville fauna, and on the other with a fauna that may be older than the Mariposa. In a second paper, Mr. Diller described the local silicification of the Knoxville beds referred to in his. first paper.

In view of the excursion planned for visiting the Grand Canyon of the Colorado after the adjournment of the meeting, the following paper in the absence of its author was read by Dr. C. W. Hayes: "Wind Erosion in the Plateau Country," by Dr. Whitman Cross of the U. S. Geological Survey. Dr. Cross laid stress upon the agency of the wind in eroding certain beds, a feature which has till recently been overlooked in discussing geologic activity in the region.

The next paper, which was by Prof. G. D. Louderback and Mr. W. C. Blasdale of the State University of California, pertained to the gem mineral benitoite, which was discovered last year in California. Benitoite is a beautiful deep sapphire-blue mineral with a toite is a beautiful deep sapphire-blue mineral with a
high index of refraction that gives great. brilliancy to gems cut from it. Unfortunately, it is too soft for hard usage, its hardness being between $51 / 4$ and $61 / 2$ of the usual scale. In chemical composition it is a titano-silicate of barium with the formula $\mathrm{BaTiSi}_{3} \mathrm{O}_{9}$.

In a paper entitled "Shoreline Studies on Lakes Ontario and Erie," Prof. Alfred W. G. Wilson of McGill University, Montreal, said in part: The initial shore lines of these lakes were very complex because of the complex character of the basins in which they lie. The process by which the shore lines have been brought to their present stage of development is almost wholly due to the action of waves and the current generated by them. Tides and other currents strong enough to be effective agents in transportation do not exist in the Great Lakes. The materials found on the shores are almost wholly of glacial origin. They are being distributed along the shores by the shore processes, and there is evidence of the existence of two nodal points on each lake, one on the north shore, and one on the south. East of these points the resultant general movement of shore débris is east, west of these points it is west. Locally there may be a any specified time movements in either direction, ac cording to the direction of the wind and waves at that time.

After the end of the reading of formal papers, Dr. C. W. Hayes informally exhibited a set of photographs of the fossil woods of Arizona, together with notes on them by Dr. David White, palæobotanist to the United States Geological Survey. Then President W. G. Tight exhibited and described a series of stereopticon slides illustrating glacial and other phenomen among the High Andes of Bolivia, and the scientific programme was declared finished.

After passing suitable resolutions of thanks to the citizens and the Commercial Club of the city of Albu- querque, to the authorities of the University of New Mexico, and particularly to President Tight for the hospitality enjoyed and the arrangements made for the meeting, the society adjourned. New Year's Day was spent in a geological excursion given by the university and the Commercial Club to the Sandia Mountains east of the city, and that night most of the members in attendance left on a special car to visit the Petrified Forest and the Grand Canyon of the Colorado. A few of the members also visited the famous Coon Butte or Meteor Crater in Arizona before they returned to their homes.

Four new fellows were elected to the Society in connection with this meeting, namely: Major Clarence Edward Dutton, U. S. A. (retired), Englewood, N. J.; Prof. D. P. Penhallow, McGill University, Montreal, Canada; Dr. Percy Edward Raymond, Carnegie Museum, Pittsburg, Pa.; Prof. Thomas Edmund Savage, University of Illinois; Urbana, Ill.

The following officers were elected for the year 1908: President, Samuel Calvin, Iowa City, Iowa; first vice-president, George F. Becker, Washington, D. C.; second vice-president, A. C. Lawson, Berkeley, Cal.; secretary, Edmund Otis Hovey, New York city; treasurer, William Bullock Clark, Baltimore, Md.; editor, J. Stanley-Brown, Cold Spring Harbor, N. Y.; librarian, H. P. Cushing, Cleveland, Ohio

\title{
ASTRONOMY WITH A THREE-INCH TELESCOPE."
}

\author{
WHAT CAN BE DONE WITH A SMALL INSTRUMENT.
}

\section{B Y W E N D E L L. PA U L.}

IT is the object of the present article to point out, while letting the mathematics of the subject entirely alone, the pleasures which may be derived through the use of a three-inch telescope, intelligently handled. An instrument of this size has much to commend it. It is of an aperture almost invariably found among amateurs, and gives perhaps better results for its aperture and expense than slightly larger or smaller instruments

Once proficient in its use, an enterprising observer has before him a mine whose treasure he can scarcely hope to exhaust, even in the leisure evenings of many years. Few professionals who have not themselves begun with small instruments seem to realize the number of objects deemed hardly worth attention with larger apertures, which can not only be picked up but well seen with a three-inch glass. Success in this case depends not so much on being able to see a thing as on knowing how to see it; a measure which can result only from experience and practice. First experiences with a telescope are generally somewhat disappointing, but a little patience and perseverance quickly rectifies the matter.

Telescopes are of two kinds, refracting and reflecting, either of which possesses its own peculiar advantages or disadvantages, but for the amateurs, the former alone is worthy of conșideration unless indeed he be of a mind to construct his own glass. Far more can be observed with a refractor than with a reflector of similar aperture; but the latter type presents less difficulty of construction and involves less skilled workmanship than the former. The most common instrument found among amateurs is of the refracting type and has an object glass of three inches diameter. The cost of such a glass varies with the excellence of the make, but an instrument suitable in every respect can be obtained for seventy-five dollars. The usual form of mount is an ordinary garden tripod which is portable and, if steady and well put together, is all that is required. The most important part of the instrument is of course the object glass, and too great care cannot be exercised to get a good one. Generally those sold by the leading opticians are reliable, but the glass should not be accepted until certain of its excellence. A number of eye pieces of various power are a necessary adjunct, as a change of power is often a great relief to the eye. The magnification employed is also dependent on the state of the weather, and the nature of the object. For planetary work a power of two hundred is not too high, under favorable circumstances. In comet sweeping, an eye piece of as low power as twenty-five diameters will be most convenient. The observer must regulate his choice to suit his need.

Probably the first object to which the beginner will turn will be the moon, and no better starting point for his celestial survey could be found. The rugged surface of our satellite presents even in a three-inch glass such a scene of grandeur that one can wonder tirelessly over its rocky fastnesses and towering mountains. When under oblique illumination these
stand out in strong relief from the lower plane, caststand out in strong relief from the lower plane, cast ing tremendous shadows upon the surrounding floor Far out beyond the terminator scattered peaks rays having already caught their lofty summits before the lower ramparts become illuminated. It is an absorbing spectacle to thus watch a sunrise upon another world, as gradually peak after peak bursts into view crowned with the golden splendor of the risin sun. The ring plains, and crater mountains with their central cones and buttressed ramparts are objects of great interest. Their volcanic origin is apparent at a glance and we everywhere see evidence of the tremendous forces which have been at work upon the surface of our satellite. Observation should be made upon the moon continuously from new until sh has again reached that position, and the various formations studied under all angles of illumination. The great plains with their ridges and tiny crater pits and the mysterious whitish streaks which cross the surface will repay many a night's study. But other objects besides the moon await the beginner, and of these let us first consider the next most closely re lated members of our system, the planets.

Of Mercury we can see vers little owing to his proximity to the sun. Even*when he has been successfully found it is quite out of the question to expect to make out surface markings. Owing to his orbit being interior to ours the little planet runs through phases similar to the moon and the best we can expect to see of him is a silver crescent in the twilight of evening or morning sky. Venus, the twin of the earth, is a much more interesting object than Mercury, but in her case, too, we are handicapped by her orbit being interior to ours. She too runs through phases similar to the moon and a charming sight she is seen with our lens. Venus is, however, one of the most difficult objects to observe owing to the flood of light in which she is deluged, and the extent of he atmosphere which reflects a great part of the light incident upon her. None but a good glass can show her well and then. we must have good seeing. Passing outward from our earth we come next to the planet Mars and in a three-inch telescope we shall find him a much more satisfactory object than eithe Venus or Mercury. At a favorable opposition dark markings can be made out and the polar caps clearly seen. Beyond Mars, Jupiter, the giant of the solar system, permits of considerable profitable study with three-inch lens, both on account of his cloud belt and surface marking as well as of his ever-circling satellite system. Here we may observe eclipseș of his four attendant moons and watch the progress of their shadows as dark spots across his disk. It was by such methods

ocity of light.

Saturn is an object of immense interest by reason of the ring which girdles him. This can be seen to great advantage with our lens, and also the dark belts upon the planet's surface similar to Jupiter. His atellites are of less interest, but four of them may be seen under favorable circumstances. Uranus and Neptune are too remote to repay much attention, and indeed they are rather unsatisfactory objects even in larger instruments.

Beyond the orbit of Neptune objects of a very different nature await us. The observation of the double stars, nebulæ, and star clusters constitutes one of the most fascinating branches, of astronomy open to us, and in the case of double stars really useful work has been performed with instruments of our aperture. In the case of the double or multiple stars the colors and magnitudes of the components should be carefully noted and the results compared with others. Extremely beautiful contrasts of color will be found among some pairs. The amateur may also test his eyesight and the quality of his lens by attacks upon double stars whose components are just within the separating power of his glass (1.52 sec.). There is a peculiar fascination in this work and when after long observation the smaller companion star suddenly, in a moment of steady seeing, flashes out from alongside its greater primary, an extremely gratifying feeling of triumph ensues.

The study of the nebulæ will give the observer an insight into the nature of these remarkable objects, as numerous examples are within the power of his lens, showing their development from hazy diffuse clouds of incandescent fire-mist into suns or clusters of suns. Among them we see illustrated the various stages through which our own system has passed in its growth.

Still other fields of work are open to the possessor of a three-inch telescope, and fields which offer opportunity of really valuable work being accomplished. These are the continued observation of variable stars and comet sweeping. Many variables are constantly being discovered by such means. In fact many have been found with no more optical aid than the opera glass. Comet sweeping if carried on diligently is very apt to result in success, but here the element of luck is very conspicuous.

To conclude, the owner of a three-inch telescope has before him a field of work both in and without the solar system with which he can occupy his leisure hours for many a night and year, and by which he may gain the intellectual pleasure which only such knowledge can inspire.

C. C. Trowbridge in the Astrophysical Journal says hat meteor trains are the luminous clouds formed by meteors which persist long after the incandescent nucleus has disappeared. The average of the heights above the earth's surface of the middle portion of the trains is 54 miles ( 87 kilometers), the minimum being about 45 miles, and the maximum 65 miles. It would thus appear that in the zone between 50 and 60 miles' altitude there exist the special atmospberic conditions necessary for the production of these phenomena. That the appearance is due to gaseous phosphorescence 